\title{
Phytochrome System of the Yeast Candida guilliermondii and Recovery from Ultraviolet Injury
}

\author{
By G. Y. FRAIKIN AND M. E. POSPELOV \\ Biology Department, Moscow State University, Moscow I I7234, U.S.S.R. \\ AND L. B. RUBIN \\ Physics Department, Moscow State University \\ (Received 25 June 1975 ; revised 29 October 1975) \\ SUMMARY
}

The effect of red $(660 \mathrm{~nm})$ and far-red $(730 \mathrm{~nm})$ light on the stability of the yeast Candida guilliermondii to lethal u.v. radiation has been studied. Reactivation and protection were exhibited for $30 \mathrm{~min}$ after treatment with red light and were abolished by far-red exposure applied within this time period. The temperature dependence of the reactivation effect was also studied. The data obtained show that the properties of recovery and protection against u.v. exposure are associated with the phytochrome system of the yeast.

\section{INTRODUCTION}

The reversible action of red (650 to $690 \mathrm{~nm})$ and far-red (700 to $750 \mathrm{~nm}$ ) light on the rate of reproduction of the yeast Candida guilliermondii was reported by Fraikin, Verkhoturov \& Rubin (1973). The action spectra of acceleration of yeast cell division in the lag phase and the photoreversibility of this effect showed maximum values at 660 and $730 \mathrm{~nm}$ respectively, and the effects of the intensity, dose and duration of $660 \mathrm{~nm}(\mathrm{R})$ and $730 \mathrm{~nm}$ (FR) light were examined. The differential spectrum FR minus $R$ light with positive maximum at $660 \mathrm{~nm}$ and negative at $730 \mathrm{~nm}$ was recorded, as well as the spectrum of yeast fluorescence with a specific maximum of $695 \mathrm{~nm}$ at $650 \mathrm{~nm}$ light excitation. From these data, we concluded that the yeast pigment system has the basic characteristics of the phytochrome system of green plants (Hendricks, Butler \& Siegelman, 1962; Briggs \& Rice, 1972; Grill, 1972). In higher plants it is known that $P_{730}$ is converted in the dark to the inactive form $\mathbf{P}_{660}$. We investigated whether this also took place with yeast phytochrome, and determined the duration of the active form in vivo.

\section{METHODS}

Candida guilliermondii was grown and prepared as described by Fraikin et al. (1974). Before the inoculation of liquid medium in a shaken flask, the cells of the sample were exposed to monochromatic light for a short time and were then cultivated under the same conditions as the control. A $1000 \mathrm{~W}$ mercury lamp and a grating spectrometer with I nm $\mathrm{mm}^{-1}$ linear dispersion were used as light sources. Cell numbers were counted in a FuchsRosental chamber. The ratio of the number of cells in the experimental sample to that in the control was regarded as a measure of the effect of the light.

An investigation into the effect of monochromatic light on the survival rate of yeasts exposed to u.v. radiation was carried out on wort agar at $30^{\circ} \mathrm{C}$ for $24 \mathrm{~h}$. For the preinoculation exposure of cells to lethal u.v. radiation at $254 \mathrm{~nm}$, a type BUV-30 bactericidal lamp was used. The survival rate of yeasts was determined by counting the microcolonies. 


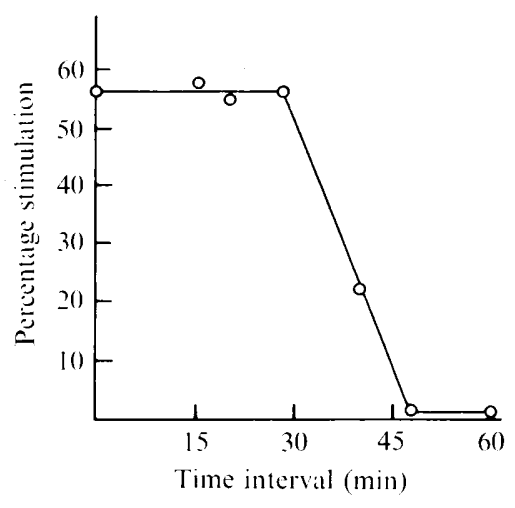

Fig. I

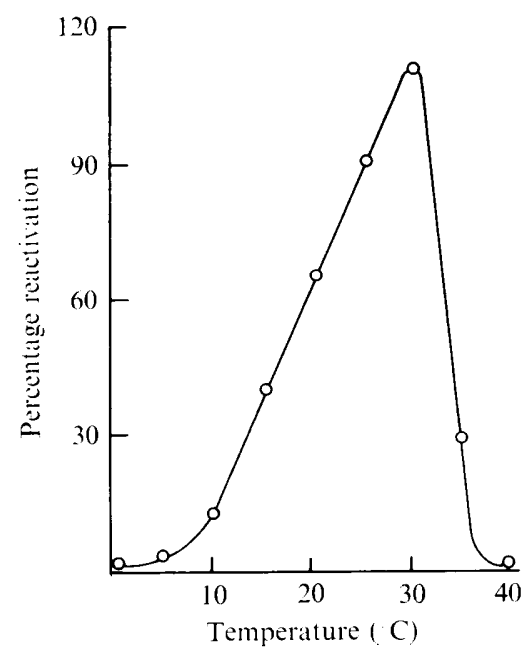

Fig. 2

Fig. I. Dependence of photostimulation of $C$. guilliermondii reproduction on the time interval between exposure to $660 \mathrm{~nm}$ light and the commencement of cultivation. Cell numbers were determined $2 \mathrm{~h}$ after cultivation commenced.

Fig. 2. Dependence of the reactivation effect of the yeast $C$. guilliermondii on temperature. The organism was held at different temperatures for a $30 \mathrm{~min}$ period after $\mathrm{R}$ light exposure.

\section{RESULTS}

Duration of phytochrome activity in C. guilliermondii cells

The samples were exposed for $5 \mathrm{~min}$ to $660 \mathrm{~nm}$ light of $2 \times 10^{-8}$ Einstein $\mathrm{cm}^{-2} \mathrm{~s}^{-1}$ intensity and kept in the dark for various periods of time before cultivation in the shaker. Two hours after the beginning of growth, cell numbers were counted in experimental and control flasks, to determine by how much reproduction was accelerated in the light-exposed culture. The photo-stimulation effect on yeast reproduction was maintained if the interval between exposure to $660 \mathrm{~nm}$ light and the beginning of cultivation was not longer than $30 \mathrm{~min}$ (Fig. I). This time period could be related either to the limited duration of phytochrome activity or to the limited survival of some intermediate chemical products of its activity. Further experiments showed that the $730 \mathrm{~nm}$ light (intensity, $\mathrm{I} \times 10^{-8}$ Einstein $\mathrm{cm}^{-2} \mathrm{~s}^{-\mathbf{1}}$; time of light exposure, to min) abolished the effect of $\mathrm{R}$ light during the $30 \mathrm{~min}$ period. From the data obtained, we concluded that $R$ light reactivation is related to the fact that the active phytochrome form in yeast persists for about $30 \mathrm{~min}$.

\section{Phytochrome-induced reactivation and protection of yeasts against lethal u.v. action}

In this series of experiments, the cells which had been irradiated with lethal u.v. radiation $\left(254 \mathrm{~nm} ; 8 \times 10^{-7}\right.$ Einstein $\left.\mathrm{cm}^{-2}\right)$ were exposed to the $660 \mathrm{~nm} \mathrm{R}$ light at an intensity of $2 \times 10^{-8}$ Einstein $\mathrm{cm}^{-2} \mathrm{~s}^{-1}$ for $5 \mathrm{~min}$, as well as $660 \mathrm{~nm} \mathrm{R}$ followed by $730 \mathrm{~nm}$ FR light (intensity $\mathrm{I} \times \mathrm{IO}^{-8}$ Einstein $\mathrm{cm}^{-2} \mathrm{~s}^{-1}$; exposure time $10 \mathrm{~min}$ ). Phytochrome activation by red light alone resulted in a 2- to 3-fold increase in the survival rate of yeasts, while FR light abolished this effect. The increased survival rate in u.v.-exposed yeasts after $\mathbf{R}$ light was abolished when FR light was applied not more than $30 \mathrm{~min}$ after the $\mathrm{R}$ light. If the dark period exceeded $30 \mathrm{~min}$, the $730 \mathrm{~nm}$ light did not eliminate the effect of the R light (Table I). 
Table I. Effect of $R$ and FR irradiation and of the time interval between them, on the photoreversibility of the reactivation effect of $u . v$. -pretreated $C$. guilliermondii

\begin{tabular}{|c|c|c|}
\hline $\begin{array}{c}\text { Time between } \\
\text { u.v. }+\mathrm{R} \text { and } \mathrm{FR} \\
\text { light exposures ( } \mathrm{min} \text { ) }\end{array}$ & $\begin{array}{l}\text { Conditions of } \\
\text { light exposure }\end{array}$ & $\begin{array}{l}\text { Survival rate } \\
\pm \text { s.D. }(\%)\end{array}$ \\
\hline 一 & u.v. & $12 \pm 0.7$ \\
\hline 一 & u.v. $+\mathbf{R}$ & $35 \pm 2 \cdot 0$ \\
\hline 0 & (u.v. + R) + FR & $13 \pm I \cdot 5$ \\
\hline IO & $(\mathrm{u} . \mathrm{v} .+\mathrm{R})+\mathrm{FR}$ & $13 \pm 1 \cdot 6$ \\
\hline 20 & (u.v. $+\mathrm{R})+\mathrm{FR}$ & $14 \pm 0.6$ \\
\hline 30 & (u.v. + R) +FR & $14 \pm I \cdot 5$ \\
\hline 40 & (u.v. +R) +FR & $34 \pm 2 \cdot 0$ \\
\hline
\end{tabular}

Table 2. Effect of the pretreatment of $C$. guilliermondii with $R$ and FR light on its survival rate following subsequent irradiation with $u . v$. light

\begin{tabular}{|c|c|c|}
\hline $\begin{array}{l}\text { Time between light } \\
\text { treatments with } R \\
\text { and u.v. or } R \text { and } \\
\text { FR + u.v. (min) }\end{array}$ & $\begin{array}{l}\text { Conditions of } \\
\text { light exposure }\end{array}$ & $\begin{array}{c}\text { Survival rate } \\
\pm \text { S.D. }(\%)\end{array}$ \\
\hline 一 & u.v. & $9 \pm 0.6$ \\
\hline 0 & $\mathbf{R}+\mathbf{u} . \mathbf{v}$. & $22 \pm I \cdot 5$ \\
\hline o & R+(FR+u.v.) & $10 \pm 0.7$ \\
\hline 30 & $\mathrm{R}+\mathrm{u} . \mathrm{v}$ & $22 \pm 0.6$ \\
\hline 30 & $R+(F R+$ u.v. $)$ & $12 \pm 0.6$ \\
\hline 60 & $\mathrm{R}+\mathrm{u} . \mathrm{v}$ & $8 \pm I \cdot 0$ \\
\hline
\end{tabular}

The reactivation effect was revealed by exposing the cells to the $660 \mathrm{~nm}$ light for only a few minutes. Moreover, the effect was shown even with one flash of a ruby laser at $694^{\circ} 3 \mathrm{~nm}$ (pulse duration $2 \times 10^{-8} \mathrm{~s}$ at $\mathrm{I} \mathrm{MW}$ ). This indicated that the increase in the survival rate of u.v.-irradiated yeasts brought about by $R$ light was associated with the conversion of phytochrome into an active form, $\mathrm{P}_{\mathbf{7 3 0}}$. In this connexion it might be assumed that phytochrome-induced reactivation includes both light and dark stages.

For the experimental solution to the above problem we plotted the temperaturedependence of the reactivation effect, varying the temperatures from 0 to $40^{\circ} \mathrm{C}$ either while the cell was exposed to $660 \mathrm{~nm}$ or during $30 \mathrm{~min}$ after R light exposure. Reactivation was independent of temperature during the period of exposure to $660 \mathrm{~nm}$, but the subsequent dark stage showed a characteristic dependence on temperature (Fig. 2).

Thus the formation of the active phytochrome form in cells resulted in the elimination of the lethal effect of u.v. irradiation. It may be assumed that the preliminary exposure to $660 \mathrm{~nm}$ light produced a protection against subsequent u.v. irradiation, provided that the dark interval between these light treatments was shorter than the time of $P_{730}$ existence.

This interpretation was confirmed experimentally, for preliminary exposure of cells to $\mathbf{R}$ light resulted in a twofold reduction of the subsequent lethal action of u.v. irradiation provided that the interval between these exposures did not exceed $30 \mathrm{~min}$. FR light used after $\mathbf{R}$ light eliminated the effect of the latter (Table 2). 


\section{DISCUSSION}

In C. guilliermondii, the phytochrome-like system activated by $\mathrm{R}$ light was able to influence the stability of the yeast to lethal u.v. radiation. Exposure to $\mathrm{R}$ light after u.v. treatment resulted in an increased rate of survival for the yeast, while illumination with a $660 \mathrm{~nm} R$ light before u.v. irradiation reduced the lethal action of the latter. The first $\mathbf{R}$ light effect is similar to photoreactivation (PR), the process of recovering from injuries caused by u.v. radiation in a biological system brought about by further exposure to light of longer wavelength. The second $\mathrm{R}$ light-induced effect can be referred to as photoprotection (PP), the process of reducing the lethal action of short-wave u.v. radiation with the help of a preradiation exposure of cells to near-u.v. light at $340 \mathrm{~nm}$ (Jagger, 1964).

The effects of reactivation and protection induced by phytochrome in C. guilliermondii differ in principle from the classic PR and PP. Indeed, the classic PR and PP are observed only with near-u.v. and blue light and photoreversibility never occurs, whereas in the present study the effects were induce $\mathcal{J}$ by $\mathrm{R}$ light and reversed by subsequently switching to $\mathrm{FR}$ light. It should be noted also that the effects of 'phytochrome' reactivation and protection are detected after exposure to $660 \mathrm{~nm}$ light for only a few minutes, or even after pulseirradiation of cells by short flashes $\left(\mathrm{IO}^{-8} \mathrm{~s}\right)$, whereas the classic $\mathrm{PR}$ and $\mathrm{PP}$ require extended illumination. Also, for the manifestation of the phytochrome-induced effect of protection, the time interval between the action of $\mathrm{R}$ light on cells and their further irradiation by shortwave u.v. irradiation is important. For the classic PP this regularity has not been established.

The differences described above demonstrate the existence in the yeast $C$. guilliermondii of quite new mechanisms of reactivation and protection from u.v.-induced injury, as against the classic processes of PR and PP.

\section{REFERENCES}

Briggs, W. R. \& Rice, H. V. (I972). Phytochrome: chemical and physical properties and mechanism of action. Annual Review of Plant Physiology z3, 293-334.

GriLl, R. (1972). The influence of chlorophyll on in-vivo difference spectra of phytochrome. Planta ro8, $185-202$.

Hendricks, S. B., Butler, W. L. \& Siegelman, H. W. (1962). A reversible photoreaction regulating plant growth. Journal of Physical Chemistry 66, 2550-2555.

JAGger, J. (1964). Photoreactivation and photoprotection. Photochemistry and Photobiology 3, 45I-462.

Fraikin, G. Y., Rubin, L. B., Yeremeyeva, O. V., Kurges, G. M., Goryukhova, N. M., Afanasyeva, V. P., Gradova, N. B., Kalunyants, K. A., Vaganova, M. S., Osipova, V. G. \& Fridman, Y. S. (1974). Practical utilization of the method of development of photostimulation and cultivation of microorganism industrial strains. Prikladnaya biokhimiya i mikrobiologiya 10, 5-10.

Fraikin, G. Y., Verkhoturov, V. N. \& Rubin, L. B. (I973). Discovery of the phytochrome system in the yeast Candida guilliermondii. Vestnik Moskovskovo universiteta 5, 54-56. 